\title{
Study on the Application of Network + Multimedia-based Process Genre Approach in College English Writing Teaching
}

\author{
Youping $\mathrm{Xu}$ \\ Neijiang Normal University, Neijiang ,641112, China
}

\section{Keywords: Network + Multimedia, Process Genre Approach, College English, English Writing}

\begin{abstract}
Process genre approach is a new kind of English writing teaching mode which is praised highly by experts at home and abroad at present. It integrates the advantages of product approach, process approach and genre approach, facilitates learners' cognition of discourse, syntax and lexical characteristics of various genres, and improves their English writing competence. On basis of college English writing teaching in colleges and universities, this paper analyzes the application of network + multimedia-based process genre approach in college English writing teaching, hoping to provide corresponding guidance for English writing teaching practice, further promote the English education quality in colleges and universities, and improve students’ English writing ability.
\end{abstract}

\section{Introduction}

As one of the four basic skills of English: listening, speaking, reading and writing, English writing has always been taken as the focus of English teaching and research. The survey results of national college students English examination committee show that college students' average writing score in CET-4 and CET-6 is merely 5-7 which is much lower than the pass level. The reason is that on the one hand teachers with outdated writing ideas lack corresponding ability cultivation of students like genre awareness, discourse construction, language expression, cooperative learning, etc in writing process, so students passively participate without benign interaction and feedback between teachers and students or among students; on the other hand, college English teaching belongs to large-class lectures, and teachers' teaching task is heavy (average 18-20 class hours with plenty of exercise correction) so it is hard for them to teach students in accordance of their aptitude.

Under the environment of network + multimedia, it is held that reforming college English writing teaching mode in colleges and universities and applying process genre approach in English writing will greatly improve the teaching effects. Therefore, this paper attempts to analyze the practical application of process genre approach in English writing teaching under the environment of network + multimedia, explores scientific teaching mode, improves English writing teaching quality, and provides corresponding guarantee for students' integrated development.

\section{Process genre approach}

In English writing teaching, three mainstream approaches-- product approach, process approach and genre approach have exerted positive influences on the wide application in writing teaching at home and abroad. However, with in-depth researches, the disadvantages and deficiencies of three writing teaching methods are also revealed clearly. Product approach follows four procedures, namely teachers' model essay analysis, students' imitation writing, teachers' correction, and teachers' comment. Even though it can guide students to take an active part in writing and grasp writing methods in writing process, the teaching of language foundation and the differences of text structure of various genres have been neglected. With the development of genre theory, process genre approach emerged in recent 10 years as a new kind of teaching method. It takes the mode of genre analysis-imitation-independent writing to carry out teaching, which is useful for students to learn genre knowledge and accomplish writing in combination of corresponding texts and communicative purpose. However, it also disadvantages like students' negative participation which has caused the "prescriptivism" color of teaching activity. 
In order to make a full use of the advantages of three teaching approaches, Badger and White in Stirling University put forward a kind of comprehensive writing teaching mode named process genre approach in 2000. It attempts to integrate the advantages of product approach, process approach and genre approach.According to the process genre approach, the writing process is turned to be a circulatory process along the direction of arrow. Teachers, students and texts can all help students to decide the context of a certain topic, and make sure the writing purpose of such kind of articles on this basis.

Process genre approach holds that writing is actually a kind of communication means constrained by contexts or social contexts and determined by communicative purpose (Eschholz, 1980). Its advantages show that teachers and students can all take an active part in writing process. This teaching approach takes model essay as reference and stimulates writing enthusiasm through procedures including discussion, imitative writing, group correction for each other, and teachers' correction.

Scholars at home like Han Jinlong (2000), Ren Rong (2005), Li Jinhong (2006), etc advocate and popularize process genre writing approach. They hold that this teaching approach not only improves learners' cognition of discourse, syntax and lexical characteristics of various genres, but also cultivates their good habit of accomplishing writing process.

\section{Application advantages of process genre approach in college English writing}

In recent years, many colleges and universities actively explore teaching modes like online class. Some colleges whose computer networks education ability was comparatively strong even combined the network development and multimedia technology innovation in China in the late 1990s, attempted to innovate and reform talent training pattern in colleges and universities, and achieved certain education effects.

Therefore, combining current multimedia network environment and constructing multimedia network English writing teaching platform is able to make a full play of the application advantages of college English writing process genre approach.

Firstly, it is able to make a full play of the teacher resource advantages of various disciplines, allocate the teacher resources, and realize the share of resources. Teachers can make corresponding teaching material. Students in learning process should choose writing genre in combination with their own interests and future major development reasonably, and constantly strengthen their writing ability of the same genre under the guidance of teachers.

Secondly, the construction of online class under multimedia network environment is able to extend traditional classroom teaching, make writing process multiple-dimensional and three-dimensional, reinforce the interaction between teachers and students, and facilitate the communication between teachers and students.

Thirdly, the openness characteristic of network environment and the teaching thought of English cooperative writing are consistent with each other. With the support of multimedia equipment and application of network teaching platform, teachers can adjust the teaching progress reasonably in accordance with students' actual learning effects, constantly collect representative genre articles in teaching practice, enrich the corpus of model essay, and provide corresponding data protection for students' independent study after class.

Finally, the advantages of process genre approach can be fully played under the environment of network + multimedia. With help of relevant multimedia equipment and software, students can timely edit and correct the articles, take advantages of strong information retrieval function for students' data inquiry, and provide corresponding support for language organization and expression ability promotion in writing. 


\section{Major framework and basic process of constructing college English writing teaching mode with application of process genre approach}

The teaching environment of process genre writing teaching mode on basis of network + multimedia takes advantage of the local area network and Internet of network teaching platform, computer room, and multimedia classroom. Process genre writing teaching mode can take the framework--model essay analysis, imitation writing, independent writing and final revision put forward by a Chinese famous scholar Han Jinlong. Therefore, teachers in teaching practice should flexibly take advantage of it to promote the college English writing teaching effects.

\section{Model essay analysis}

Firstly, teachers in concrete teaching practice set specific implementation scheme in combination with the curriculum introduction of college English writing teaching and teaching objectives of their own colleges, and provide 2-3 articles of a certain genre like narrative writing, expository writing, descriptive writing, argumentative writing and practical writing in classroom instruction process which can be taken as model essay for students' imitation writing. After class, students can collect model essay and material of various genres through Internet in groups (with 4-5 people in a group) and realize interchange and communication among groups. It can not only improve students' reading interest but also enable students to contact with language material as much as possible. Secondly, for reason that teachers can only offer students limited model essay of a certain genre in English writing teaching practice, teachers under environment of network + multimedia can also recommend relevant writing website to students, create teaching platform, expand teaching fields, and practically reinforce teaching effects. Finally, with the teaching assistant and guidance of teachers, students can take advantage of internet communication platform, conduct discussion and analysis on various model essays of a certain genre, and form the "schematic structure" of discourse. For example, through learning model essay, schematic structure on multimedia display stand can intuitively present the discourse organization structure of an argumentative writing named

“The Advantages and Disadvantages of Living in the City or in the Country" . Its discourse pattern is shown as follows:

Part I. Opening Part (topic introduction)

Part II. Comparison Analysis (contrastive analysis)

Advantages of Living in the City (topic sentence)

(developing sentence viewpoint)convenience, more developing chances, earn money, education, medical care, entertainment

Disadvantages of Living in the City(topic sentence)

(developing sentence viewpoint)pollution, crowded space, traffic jam, living pressure, indifference

Advantages in the Country(topic sentence)

(developing sentence viewpoint)air fresh, beautiful scenery, free, natural food, friendly,

Disadvantages of Living in the Country(topic sentence)

(developing sentence viewpoint)poor transportation, education and hospital, inconvenient, heavy manual work, solitude

Part III. Concluding Part (conclusion paragraph)

According to the outline above, students can stand on an objective and fair footing, and adopt the point-by-point analysis of comparison \& contrast method in the second part to make comparison of respective advantages and disadvantages of $\mathrm{A}$ and $\mathrm{B}$ after putting forward an argument in first part. That is to say, students firstly describe part A and then describe part B, namely A 1,A 2,A 3;B 1,B 2,B 3. After making comparison of respective advantages and disadvantages of $A$ and $B$, students state their personal opinions and reasons in the conclusion paragraph.

\section{Imitation writing}

Students can learn various genres and language features through intentional imitation and greatly improve their writing ability. The implementation of imitation writing process can be grouped into four links. Firstly, teachers summarize students' discussion and analysis on model essays of a certain 
genre in Internet forum at previous stage and design corresponding imitation writing topics in accordance with this genre; secondly, students discuss the social background, basic communicative objectives, tasks and contents of writing topics and accomplish the writing outline in accordance with the topics assigned by teachers; thirdly, teachers can divide students into various groups in accordance with their actual learning conditions, refine and supplement the achieved writing outline in last link in groups, and conduct group imitation; fourthly, within teachers' limited time, each group should upload and display their imitative articles in network teaching forum through multimedia equipment, and make evaluation for the imitative products under teachers' guidance.

\section{Independent writing}

In independent writing teaching process, teachers should share and display the writing background and specific topic of this time through corresponding network online teaching platform, and ask students to make independent analysis in combination with specific situations and topics provided by teachers, accomplish the writing outline by applying the relevant knowledge of the same genre, and finish the first draft.

\section{Revision and review}

Process genre approach holds that writing is a kind of communicative activity, and a kind of circulatory process for meaning discovery and meaning innovation. Mistakes are inevitable in writing process, but the writers can correct the mistakes through feedback, conduct constant correction and improvement, and finally finish the final draft.

Revision and review is also made up of four significant parts. Firstly, after students finish the first draft of English writing, teachers will organize the students to use WPS software to conduct independent revision and review of their English writing; secondly, after the first review, students can send their writing to other group members through blogs, E-mail, QQ, Campus Network, and other forms, realizing mutual review of group members; at last, after the mutual review and second modification, students can send their writing to teachers, and the teachers will conduct the revision and review.

\section{Conclusion}

In conclusion, on basis of current information technology background and the actual situations of college English writing teaching, it is rather feasible and necessary to apply process genre approach in college English writing teaching practice, construct corresponding teaching mode, and cultivate students' independent writing ability. It exerts an active influence on the improvement of teaching effects. Therefore, English teachers in colleges and universities should strengthen their focus on college English writing process genre approach, actively apply process genre approach in teaching practice, provide richer English writing teaching and training ways for students, cultivate students' English writing ability, and set foundation for students' future development.

\section{Acknowledgments}

This paper belongs to an education reform project of Neijiang Normal University with the project name as Study on the Application of Process Genre Approach in College English Writing Teaching and the project number as JG201321_247.

\section{References}

[1] Zhao Xia. Study on the English writing “process genre approach” application mode under network environment. Journal of zhejiang Wanli University, 2013, 26(1):113-116.

[2] Li Ping, Qi Meng, Zhang Guoying. Network English writing teaching practice based on constructivism. China Medical Education Technology, 2013(4):442-444.

[3] Xu Haitao. Study on the interaction of English writing and negative language transfer under network environment. Science \& Technology Information, 2011(13):190-191. 
[4] Wu Caiqin. On effective English writing teaching under network environment. Journal of Yulin Normal University, 2011,32(1):148-151.

[5] Liu Zheng. Vocational English writing teaching reform on basis of language platform. Modern Corporate Education, 2011(20):35-36. 